\title{
BLENDED LEARNING THROUGH ELENA PAGE AS A MORPHOLOGY LEARNING MEDIA
}

\author{
Diyamon Prasandha ${ }^{1}$, Harits Agung Wicaksono ${ }^{2}$ \\ \{diyamonprasandha@mail.unnes.ac.id ${ }^{1}$, haritsagungwicaksono@gmail.com ${ }^{2}$ \} \\ ${ }^{1,2}$ Universitas Negeri Semarang, Indonesia
}

\begin{abstract}
In facing the era of disruption in the 21 st century, the role of educators is required to be able to master digital technology. In the realm of learning, the use of innovative media and the enactment of online systems is a variation of face to face learning. Through the use of blended learning, it is expected to be able to overcome the learning problem. The use of elena.unnes.ac.id page can encourage students to learn independently. The research method used is qualitative descriptive. The data collection techniques used observation, interviews, and documentation. The results achieved in this study are the interaction between lecturers and students in the process of blended learning. Besides, through the elena.unnes.ac.id page, it also functions as a discussion forum between lecturers and students and it can also be used as an online assignment so that the learning process can run more effective and interesting.
\end{abstract}

Keywords: blended learning, effectiveness, learning media.

\section{Introduction}

The change of civilization to a knowledge society requires educators to master 21 stcentury skills, namely being able to understand and utilize information and communication technology (ICT Literacy Skills. Along with the rapid development of information technology (IT), the need for a concept and mechanism of teaching and learning based on technology or the use of e-learning[1]. Education plays a crucial and strategic role in building enlightened societies that have skills as follows (1) be educated of media technology, (2) conducting effective communication, (3) thinking critically, (4) solving problems and (5) collaborating. The existence of online learning makes 21 st-century educators creative and innovative in utilizing media for web-based learning. In general, it has developed that the perception of learning models that are commonly used are teacher centre rather than student centre. The use of digital media can also present issues related to student learning behaviour and educator attitudes with the rise of online learning. In carrying out literacy activities, of course it also must pay attention to the characteristics of students. Characteristics of students at this time dominated by generation $\mathrm{Z}$ (generation who born in 1998-now). Generation Z is also called Net Generation with the following characteristics: (a) having fast access to information from various sources, (b) can do several things at the same time (multitasking), (c) interested in multimedia things (d) prefer to interact with social media (Facebook, Twitter, BBM), and (e) prefer applicable things and fun in learning[2]. Based on these characteristics, new problems arise, for example, Google's reliance on being an all-knowing search engine in overcoming problems and assignments on campus. In this case, it needs assistance and evaluation to 
minimize the plagiarism of students' assignments. It is argued that social media has the potential to bridge formal and informal learning through participatory digital cultures[3]

Every change will provide opportunities, as well as challenges. Challenge with onlinebased literacy is the effort to integrate character education. Through the use of digital media as a media of literacy, it should not rule out the character education of students. Strengthening the technological literacy movement can be conducted by integrating literacy activities with the character of students. Character is related to a person's performance in interacting with their environment. Character is related to a person's overall performance in interacting in their environment. Education for character development is an important part of human life to shape a human identity for the creation of a civilized and moral person[4] The learning process by using blended learning can foster creativity and insight for students. Conventional learning is conducted through centralized communication. This is not effective by considering the number of students who maybe have a large number in the classroom so that the attention to the learning material reduces due to several factors. By implementing blended learning as the best solution, students can directly interact with the teacher wherever they are without any limitations on space and time.

In the era of disruption, technological advances must be utilized as much as possible, including in the teaching and learning process. One of the ideas that can be used in this regard is blended learning, by combining face-to-face learning and online learning, it is expected that it can complement the lack of face-to-face learning and online learning. This study highlights the importance of integrating online modules with classroom learning and the role of blended learning in improving academic performance[5]

Based on e-learning analysis in the sense that students have high accessibility at $91 \%$, with mild use of $83 \%$. A good assessment of students' perceptions of e-learning, provides a great role in the implementation of learning with e-learning, which can be done with a blended learning pattern as a form of learning that collaborates with e-learning face-to-face[6]

Universitas Negeri Semarang as a university that has begun in implementing blended learning has a special page for students. Students and lecturers can access blended learning in elena.unnes.ac.id page.

The Department of Indonesian Language and Literature at UNNES is taught a Morphology course. Morphology is a sub-discipline of linguistics that examines the process of word-formation. In learning on campus, Morphology was learned conventionally is learning that is centered on lecturers. Morphology learning continued face-to-face between lecturers and students in the classroom. By utilizing available materials, such as blackboards, power points, and reference books, lecturers deliver learning materials for students. This is a consideration of the Morphology is an exact science that is requested in certain rules. It needs expert assistance to learn to teach Morphology so that lecturers still provide a complete explanation of the learning material. Lecturers still consider the need for face-to-face meetings to ensure that students truly understand the material being taught.

Such learning patterns, certainly not relevant to the times. In this digital age, most human activities are supported by systems. Of course, this system provides humans in carrying out activities. Application of a system based model can improve time efficiency and evaluate where learning activities take place. Learning activities can be done anytime and anywhere by mutual agreement, especially in learning Morphology that still adheres to the conventional system. It is necessary to reform the learning model to improve the capability or quality of the output.

Based on the introduction, it is known that in the Morphology course learning the role of lecturers is still dominant in the learning process. The learning process is not yet maximizing 
the use of e-learning based media. By implementing blended learning in morphological learning, it can be useful and improve student interaction with fellow students and students with lecturers, especially the availability of unlimited learning resources. The creation of a community of students and lecturers who interacts each other so that they can give and receive and there are no problems with location and place. Besides, it also can improve the quality of teaching and learning both lecturers and students. It is because information can be obtained more broadly and unlimitedly

\section{Methodology}

This type of research is qualitative with a descriptive approach. Qualitative research is research that intends to understand the phenomena experienced by research subjects. The phenomenon can be in the form of behaviour, perspective, motivation, actions and others holistically. The phenomenon is written by describing in the form of words and language by utilizing various natural methods[7]. The population consists of subjects who have the qualities of certain characteristics applied by researchers to be studied and then drawn conclusions[8]. The population of this research was students in Morphological course of the Department of Indonesian Language and Literature, UNNES. The total number of students is 100 students. The technique of data collection was blended learning. This method used direct observation of students and conducted an interview. The data analysis technique used is testing the validity of qualitative data because the validity of the data is one of the earliest truths of data analysis. This research is in line with the ongoing research process that has been carried out since the beginning of data retrieval, namely since data reduction, data presentation, and drawing conclusion or verification. The data analysis was carried out qualitatively using repetitive and continuous between data collection and data analysis, both of during data collection and after the data is collected.

\section{Finding(s) and Discussion}

Based on the results of the questionnaire data, it shows that students are very enthusiastic about learning blended learning using the Elena system. The obstacle found was the execution of the task. Therefore the need for a programmed guidance process would prevent delayed work. The supervisor, in this case, has a duty in assisting learning. Students feel the use of blended learning as a learning media during the learning process. The questionnaire was taken online. The interaction between lecturers and students went well. It can be seen from the accuracy of students in the collection of assignments and the activeness of students and lecturers in brainstorming ideas in online discussions.

Data analysis results are presented in the form of a percentage that focuses on four aspects of excellence using elena in learning morphology. The four fields are, among others, students motivation, effectiveness learning, learning outcomes, and minimization of learning costs. The following are the results of the questionnaire data that were approved by students who took elena-based morphology learning programs.

\begin{tabular}{llllll}
\hline Aspects & $\begin{array}{c}\text { Very } \\
\text { high }\end{array}$ & High & Medium & Low \\
\hline Motivate students to participate in learning & $81 \%$ & $12 \%$ & $5 \%$ & $2 \%$
\end{tabular}




\begin{tabular}{|c|c|c|c|c|}
\hline $\begin{array}{l}\text { Increase the effectiveness of learning } \\
\text { activities }\end{array}$ & $70 \%$ & $18 \%$ & $7 \%$ & $5 \%$ \\
\hline Improve learning outcomes & $82 \%$ & $11 \%$ & $4 \%$ & $3 \%$ \\
\hline $\begin{array}{l}\text { Minimize the operational costs of learning } \\
\text { activities }\end{array}$ & $72 \%$ & $14 \%$ & $6 \%$ & $8 \%$ \\
\hline
\end{tabular}

There are four beneficial aspects of learning to use elena. These four aspects have a positive effect on both students and lecturers as promoters of learning. Based on the analysis of the analysis data obtained, most students were very interested in learning Morphology using elena. Students feel motivated by the flexibility of space and time. Students can streamline the time, energy, and costs used to support morphological learning. By being in their respective homes, time and energy for travel can be cut. In addition, students and lecturers do not need to pay for gasoline or pay for public transportation services. From this, the effectiveness of learning will be further increased.

Student learning motivation is directly proportional to the results obtained. Based on the data analysis table, the percentage increase in morphological learning outcomes can be said to be high. Many students have experienced a growth in the quality of their understanding of morphological material. They are considering that elena-based learning is very effective in increasing student activity in discussions. Students can freely even eliminate their fear in expressing ideas. Elena can also minimize the use of operational costs. In addition to the cost of travelling to campus, electricity bills, the use of stationery, as well as maintenance of learning support facilities, can be cut. So that elenene-based learning can be an alternative for other learning activities to improve the quality and quantity of learning.

In line with Agustina's that the use of e-learning as a learning media and found that in the use of e-learning as a learning media in the university is in good condition with a total percentage of $60 \%$ and the learning model will continue to be improved to the maximum extent possible from e-learning characteristics[1]. Through the implementation of blended learning which is used as a learning media, students have an opinion that blended learning is something new so that students are always active in the learning process. Creativity arises when students are in the process of learning activities. Obstacles faced by students when collecting assignments happened when the infrastructure was disruption. Students always use devices. It causes the appearance of displays in devices is not maximum.

Bell's research entitled E-Learning in Educational Postsecondary [9] states that academics and institutions need to collaborate to address the challenges surrounding academic integrity in online environments, devise effective support systems for under prepared learners, evaluate the economic models that underlie e-learning, and understand how to deliver e-learning across geographic and cultural boundaries. This strongly supports the creation of a quality e-learning model, taking into account its suitability with various locations and social strata of students. In addition, the implementation of learning models based on e-learning has strived so as not to consume a lot of budgets. It must be considered how the most appropriate design in making it happen. Because based on a lot of research, elearning learning has many benefits for its users. So that e-learning learning must be carried out to adjust the times and make learning activities more efficient. Research on blended learning was also carried out who stated that blended learning could minimize the shortcomings that exist in face-to-face learning[10]. Blended learning can make the teaching 
and learning process more effective and efficient in achieving the objectives of learning than if only relying on the process of face-to-face learning or online learning.

\section{Conclusion(s)}

The use of blended learning as a learning media for Morphology course at the Department of Indonesian Language and Literature at Universitas Negeri Semarang will have an impact on the process of effective and interesting learning activities in accordance with the current disruptive era. Student competence in the Morphology course will increase along with the enthusiasm of students in online study and the elena.unnes..ac.id page makes a page for learning and interacting between lecturers and students.

In addition, the benefits of e-learning can also have many benefits. In this study, four aspects that are beneficial for learning are preferred, that is: 1) students motivation, 2) effectiveness learning, 3) learning outcomes, 4) and minimization of learning costs. These four aspects can improve the efficiency of learning.

\section{Reference}

[1] M. Agustina, "Pemanfaatan E-Learning sebagai Media Pembelajaran," Semin. Nas. Apl. Teknol. Inf., no. 12, pp. 8-12, 2013.

[2] T. Susana, "Kesetiaan pada Panggilan di Era Digital," Orientasi Baru, vol. 21, no. 1, pp. $55-78$.

[3] C. Greenhow and C. Lewin, "Social media and education: reconceptualizing the boundaries of formal and informal learning," Learn. Media Technol., vol. 41, no. 1, pp. 6-30, 2016.

[4] D. Dalmeri, "PENDIDIKAN UNTUK PENGEMBANGAN KARAKTER (Telaah terhadap Gagasan Thomas Lickona dalam Educating for Character)," Al-Ulum J. Stud. Islam, vol. 14, no. 1, pp. 269-288, 2014.

[5] J. E. McLaughlin, N. Gharkholonarehe, J. Khanova, Z. M. Deyo, and J. E. Rodgers, "Instructional design and assessment the impact of blended learning on student performance in a cardiovascular pharmacotherapy course," Am. J. Pharm. Educ., vol. 79, no. 2, 2015.

[6] M. F. Saifuddin, "E-Learning dalam Persepsi Mahasiswa," J. VARIDIKA, vol. 29, no. 2, pp. 102-109, 2018.

[7] L. J. Moleong, Metodelogi Penelitian Kualitatif. Bandung: Remaja Rosdakarya, 2010.

[8] Sugiyono, Metode Penelitian Pendidikan Pendekatan Kuantitatif, kualitatif, dan $R \& D$. Bandung: Alfabeta, 2010.

[9] B. S. Bell, J. E. Federman, B. S. Bell, and J. E. Federman, "E-Learning in Postsecondary Education," SPRING, vol. 23, no. 1, pp. 165-185, 2015.

[10] I Wayan Redhana, "Prosiding Seminar Nasional Pendidikan Kimia , ISBN : 978-60260306-5-8 Jurusan PMIPA FKIP UL M Banjarmasin , 17 November 2018 ' The Innovation of Chemistry Education in Confron ting Disruption Era to Build Excellent and Productive Generation '| 1 Prosidi," no. November, pp. 1-19, 2018. 